\title{
South American Climate during the Early Eocene: Impact of a Narrower Atlantic and Higher Atmospheric $\mathrm{CO}_{2}$
}

\author{
Xiaojuan LiU, David S. Battisti, And Rachel H. White \\ Department of Atmospheric Sciences, University of Washington, Seattle, Washington \\ PAUl A. BAKER \\ Division of Earth and Ocean Sciences, Duke University, Durham, North Carolina
}

(Manuscript received 1 March 2019, in final form 7 October 2019)

\begin{abstract}
The Cenozoic climate of tropical South America was fundamental to the development of its biota, the most biodiverse on Earth. No previous studies have explicitly addressed how the very different atmospheric composition and Atlantic geometry during the early Eocene (approximately 55 million years ago) may have affected South American climate. At that time, the Atlantic Ocean was approximately half of its current width and the $\mathrm{CO}_{2}$ concentration of Earth's atmosphere ranged from $\sim 550$ to $\sim 1500 \mathrm{ppm}$ or even higher. Climate model simulations were performed to examine the effects of these major state changes on the climate of tropical South America. Reducing the width of the Atlantic by approximately half produces significant drying relative to modern climate. Drying is only partly offset by an enhancement of precipitation due to the higher $\mathrm{CO}_{2}$ of the early Eocene. The main mechanism for drier conditions is simple. Low-level air crosses the tropical Atlantic from North Africa in much less time for a narrower Atlantic (2 days) than for the modern Atlantic ( $\sim 6$ days); as a result, much less water is evaporated into the air and thus there is far lower moisture imported to the continent in the Eocene simulation than in the modern control. The progressive wetting (during the mid- to late Cenozoic) of the Amazon due to the widening Atlantic and the rising Andes, only partly offset by decreasing $\mathrm{CO}_{2}$ values, may have been partly responsible for the accumulating biodiversity of this region.
\end{abstract}

\section{Introduction}

Tropical South America, with its Andean and Amazon forests, is the most biodiverse region on Earth (Antonelli et al. 2018). It is believed that this biodiversity remained steady (e.g., Close et al. 2019) or increased (e.g., Condamine et al. 2012) through the Cenozoic [approximately 66 million years ago (Ma) to the present day], perhaps because of a relatively stable, warm, and wet tropical climate. Following the breakup of Gondwanaland and the opening of the South Atlantic Ocean, beginning effectively in the early Cretaceous ( $\sim 140 \mathrm{Ma})$, the South American continent separated from Africa along a nearly zonal trajectory. Throughout the entire Cenozoic, the present-day South American equator was within $3^{\circ}$ distance from its current latitude (Seton et al. 2012); that is, tropical South America has occupied approximately the same latitude for nearly the

\footnotetext{
Corresponding author: Xiaojuan Liu, xjliu@uw.edu
}

entire (largely Cenozoic) history of its angiospermdominated rain forest. However, during this same time period, the Atlantic Ocean more than doubled in width, global $\mathrm{CO}_{2}$ apparently decreased dramatically along with global temperatures, and the Andean Cordillera achieved its current altitude, becoming a formidable, continuous, longitudinal orographic barrier. All three factors surely played significant roles in the evolving climate and biodiversity of the South American tropics. The development of several more distal geographic features, such as the opening of the Drake Passage (about $40 \mathrm{Ma}$; Scher and Martin 2006; Lagabrielle et al. 2009), the progressive northward drift of the African plate (Nilsson et al. 2013), the posited initiation of the Pacific Walker circulation during the Pliocene (e.g., Wara et al. 2005), and the closure of the Isthmus of Panama (e.g., O’Dea et al. 2016), may also have affected the evolving Cenozoic climate of South America.

The deep-sea oxygen isotopic record from benthic foraminifera indicates that the early Eocene ( $\sim 55 \mathrm{Ma})$ 
was the warmest period on Earth in the past 65 million years (Zachos et al. 2001). Estimates of the global mean surface temperature at that time range between $4^{\circ}$ and $14^{\circ} \mathrm{C}$ greater than the preindustrial value (Jones et al. 2011; Caballero and Huber 2013). Atlantic tropical sea surface temperatures may have peaked at $35^{\circ} \mathrm{C}$ during the early Eocene and at $38^{\circ} \mathrm{C}$ during the PaleoceneEocene thermal maximum (PETM) event ( $\sim 56 \mathrm{Ma})$ (Cramwinckel et al. 2018). The warm Eocene is likely a result of both higher atmospheric $\mathrm{CO}_{2}$ and the different plate tectonic-related configuration of oceans and continents. Compared to today, the Eocene was characterized by a narrower Atlantic basin, a narrower and shallower Drake Passage, a more southward position of Australia and Africa, an open Panama seaway, land connections between North America and Europe through Greenland, and an Indian subcontinent isolated from Asia (Seton et al. 2012). Although a multimodel comparison (Lunt et al. 2012) finds that atmospheric $\mathrm{CO}_{2}$ concentrations of $2500-6500 \mathrm{ppm}$ yield optimal agreement with climate model results, a recent review of actual proxy determinations concludes that the most reliable atmospheric $\mathrm{CO}_{2}$ concentrations were in the range of $1000 \pm 500 \mathrm{ppm}$ throughout most of the Eocene (Anagnostou et al. 2016).

Pollen data from Colombia and Venezuela suggest that the biodiversity of northern tropical South America rain forest reached a maximum during the early Eocene (Jaramillo et al. 2006), possibly exceeding modern-day values, despite, or perhaps because of, the greater global mean surface temperature and higher atmospheric $\mathrm{CO}_{2}$ concentration. The high biodiversity during the early Eocene indicated by the pollen data is also thought to be due in part to a humid climate in tropical South America (Jaramillo et al. 2006), but there are as yet no paleoclimate records from the Amazon that can substantiate or refute this hypothesis. On the other hand, many studies have explored the global climate of the early Eocene using numerical models (Huber and Sloan 2001; Huber et al. 2004; Heinemann et al. 2009; Lunt et al. 2010; Winguth et al. 2010; Huber and Caballero 2011). While the goal of each of these studies was to reproduce the global climate of the early Eocene using realistic boundary conditions and forcings, the studies did not allow for the attribution of the observed large-scale climate changes of the period.

Of the three factors that we previously identified as most likely to be paramount in forcing the Eocene climate of tropical South America-Andean uplift, the narrower Atlantic, and higher concentrations of atmospheric $\mathrm{CO}_{2}$-only the first has been the subject of focused study. In fact, several previous climate modeling studies have explicitly addressed the question of the impact of the Andes on the climate of tropical South America. In all models (Lenters and Cook 1995; Garreaud et al. 2010; Ehlers and Poulsen 2009), the rate of precipitation in most parts of tropical South America is dependent on the presence of a continuous, high, northsouth-oriented Andean Cordillera. For example, Lenters and Cook (1995) found that the presence of the Andes produced higher orographic precipitation over the eastern flanks of the range and higher precipitation in the eastern lowlands due to an intensified South American summer monsoon, when compared to their "no-mountains" simulation. Likewise, Garreaud et al. (2010) found that Andean topography intensified the South American summer monsoon and produced a broad region of increased precipitation from the southern Amazon to the southern subtropics of South America, while equatorial South America became drier. Although the results of the climate simulations are broadly consistent, the timing of Andean uplift itself is poorly known. Considerable paleoaltimetry data exist for the eastern Cordillera, but there is a dearth of such data for the western Cordillera, the volcanic arc, throughout much of the Andes. That said, it has been proposed (Garzione et al. 2017) that in the Central Andes a western Cordillera with elevation $\geq 2 \mathrm{~km}$ was attained prior to $45 \mathrm{Ma}$. As previous modeling results have shown a nonlinear response of precipitation to elevation, such that raising Andean elevations above $2 \mathrm{~km}$ produced much less climate response than values below $2 \mathrm{~km}$ (Takahashi and Battisti 2007; Garreaud et al. 2010), we have taken the liberty of using modern topography in our current study. In any case, if the Eocene Andes were far lower than modern, the dry Eocene conditions that we simulate in our study would only have been further exacerbated.

\section{Model and experimental design}

For this study, we used the ECHAM atmospheric general circulation model, version 4.6 (ECHAM4.6; Roeckner et al. 1996). The ECHAM model is a spectral model with T42 resolution (approximately $2.8^{\circ}$ in latitude and longitude) with 19 vertical levels, and is coupled to a 50-m slab ocean. We first perform a modern-day experiment (called Wide_353CO2), whereby the model is configured with present-day continental geometry, orography, and orbital parameters; and with an atmospheric $\mathrm{CO}_{2}$ concentration of $353 \mathrm{ppm}$, and other greenhouse gas concentrations and aerosol distributions from 1850 (Table 1). A climatological $Q$ flux with seasonal cycle is prescribed to the slab ocean in the modern-day simulation to account for the ocean heat flux convergence by ocean currents and for biases in the surface heat flux due to biases in the atmospheric model. Using 
TABLE 1. Experiments performed in this study.

\begin{tabular}{|c|c|c|c|c|}
\hline & \multicolumn{4}{|c|}{ Experiments } \\
\hline & Wide_353CO2 (modern day) & Narrow_1000CO2 (early Eocene) & Wide_1000CO2 & Narrow_353CO2 \\
\hline Continental geometry & Modern & Narrow Atlantic & Modern & Narrow Atlantic \\
\hline $\mathrm{CO}_{2}$ concentration & $353 \mathrm{ppm}$ & $1000 \mathrm{ppm}$ & $1000 \mathrm{ppm}$ & 353 ppm \\
\hline Other boundary conditions & Preindustrial & Preindustrial & Preindustrial & Preindustrial \\
\hline
\end{tabular}

ECHAM 4.6 coupled to a slab ocean does not allow for changes in the ocean circulation; possible effects of ocean circulation change are explored in section $4 \mathrm{~b}$.

There were certainly many geometric and forcing differences of importance to the global climate of the early Eocene. But in this study, for reasons elucidated previously, we isolate the impact of the two factors that we believe were important in shaping the Eocene climate of tropical South America: a narrower Atlantic Ocean and a higher atmospheric $\mathrm{CO}_{2}$ concentration. We undertake a Narrow_1000CO2 experiment, in which the atmospheric $\mathrm{CO}_{2}$ concentration is set at $1000 \mathrm{ppm}$, well within the range of estimates of $\mathrm{CO}_{2}$ concentration at the early Eocene reconstructed from proxy data (Beerling and Royer 2011; Anagnostou et al. 2016), and the Atlantic Ocean is narrowed by removing a $25^{\circ}$ longitude strip from the Atlantic Ocean, while the Pacific Ocean is stretched by $25^{\circ}$ longitude. The resulting "narrow Atlantic" is close to the Atlantic geometry reconstructed for the early Eocene (Seton et al. 2012). The $Q$ flux used in the Narrow_1000CO2 experiment is the same as that in the modern-day experiment, except that it is zonally symmetrized in the Atlantic basin and uniformly zonally stretched in the Pacific; a small longitudinally invariant correction is then added to the $Q$ flux so that the zonally integrated ocean heat flux at each latitude is identical to that in the modern-day experiment (see discussion in section $4 \mathrm{~b}$ ). We also refer to the Narrow_1000CO2 experiment as the early Eocene experiment.

To isolate the impact of a narrower Atlantic basin and the impact of higher atmospheric $\mathrm{CO}_{2}$ on precipitation and temperature, we perform two further experiments: Wide_1000CO2 is the same as the modern-day experiment except that the atmospheric concentration is set to be 1000 ppm, and Narrow_353CO2 is the same as Narrow $1000 \mathrm{CO} 2$ except for a $353 \mathrm{ppm} \mathrm{CO}_{2}$ concentration. Differences between Wide_1000CO2 and Narrow 1000CO2, or between Wide_353CO2 and Narrow_ $353 \mathrm{CO} 2$, isolate the effects of narrowing the Atlantic with atmospheric concentrations of 1000 and $353 \mathrm{ppm}$, respectively. Differences between Wide_1000CO2 and modern-day experiment, or between Narrow_1000CO2 and Narrow_353CO2, isolate the effect of increasing atmospheric $\mathrm{CO}_{2}$ concentration, given two different geometries. To explore whether the major conclusions are sensitive to the choice of model, all four experiments were repeated using CESM 1.2; the main conclusions are robust to the choice of models. We focus on the results from the ECHAM 4.6 model, which has a better modernday precipitation climatology in tropical South America than does the modern-day CESM 1.2 simulation.

\section{Results}

\section{a. Modern-day climate}

Seasonal and annual mean precipitation and $925-\mathrm{hPa}$ winds in observations (left panels of Fig. 1) are compared with the modern-day control simulation (middle panels of Fig. 1). Three major circulation systems characterize much of the precipitation of tropical South America [see the review by Garreaud et al. (2009) for more details]: the Atlantic intertropical convergence zone (ITCZ), the South American monsoon system (SAMS) (Zhou and Lau 1998; Vera et al. 2006) over continental South America, and the South Atlantic convergence zone (SACZ). The Atlantic ITCZ is associated with the convergence of trade winds over the ocean from both hemispheres. The Atlantic ITCZ migrates north-south seasonally following the sun and is responsible for the rainy season of northeastern Brazil in austral autumn (March-May), when it reaches its southernmost position. South American monsoonrelated precipitation also follows the migration of the sun: it is centered over northwestern South America in the austral spring, expands southward and eastward from austral spring to austral summer, and then retreats to the northwest from austral fall to austral winter. In austral summer, the SAMS brings precipitation to almost all of tropical South America, reaching as far south as $30^{\circ} \mathrm{S}$. The SACZ forms due to the convergence of the midlatitude westerly flow with northwesterly flow along the western flank of the South Atlantic anticyclone (Kodama 1993; Lenters and Cook 1995; Nogués-Paegle and Mo 1997); the passage of extratropical transient frontal systems contributes to the southern portion of the SACZ (Garreaud and Wallace 1998). The SACZ is present year-round, but it is most intense during austral 
Observation
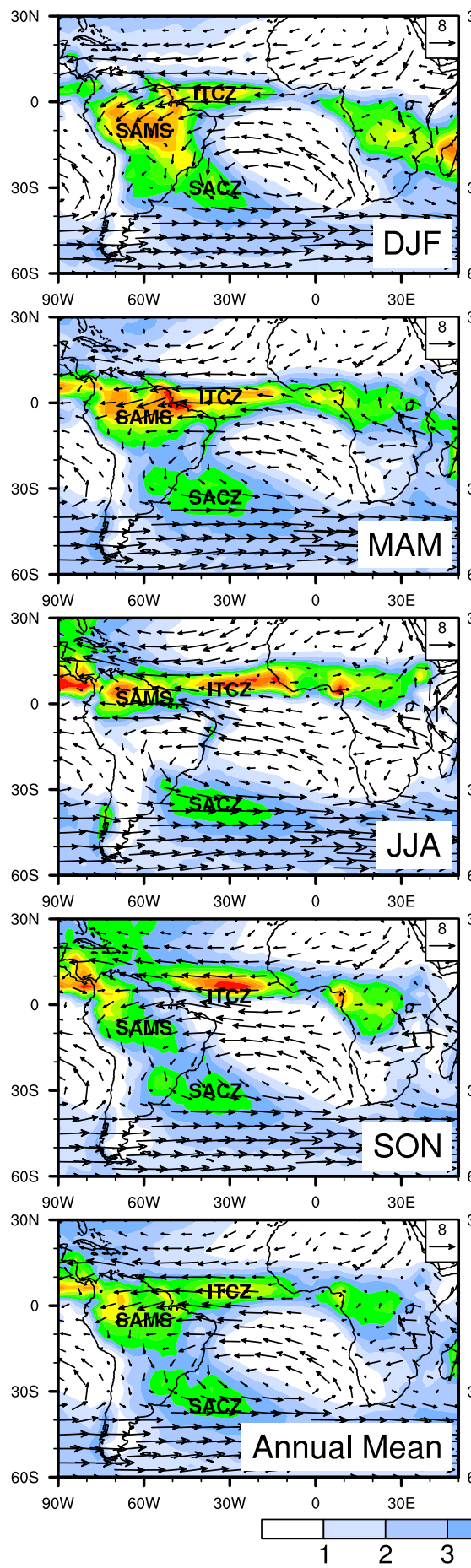

Modern day
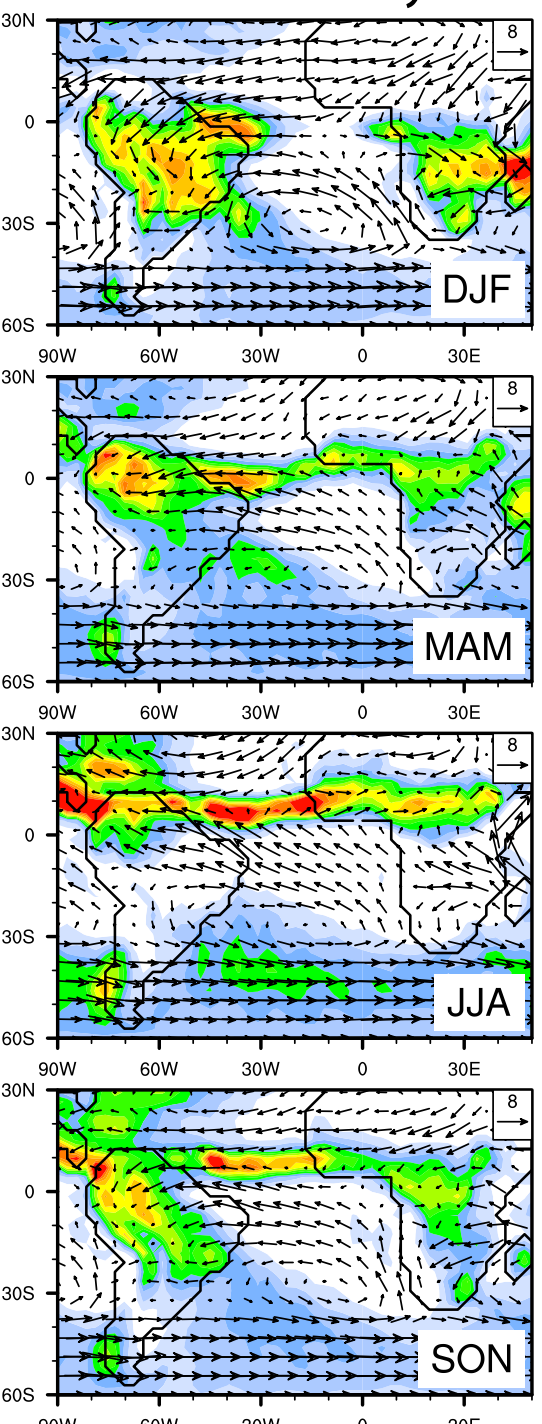
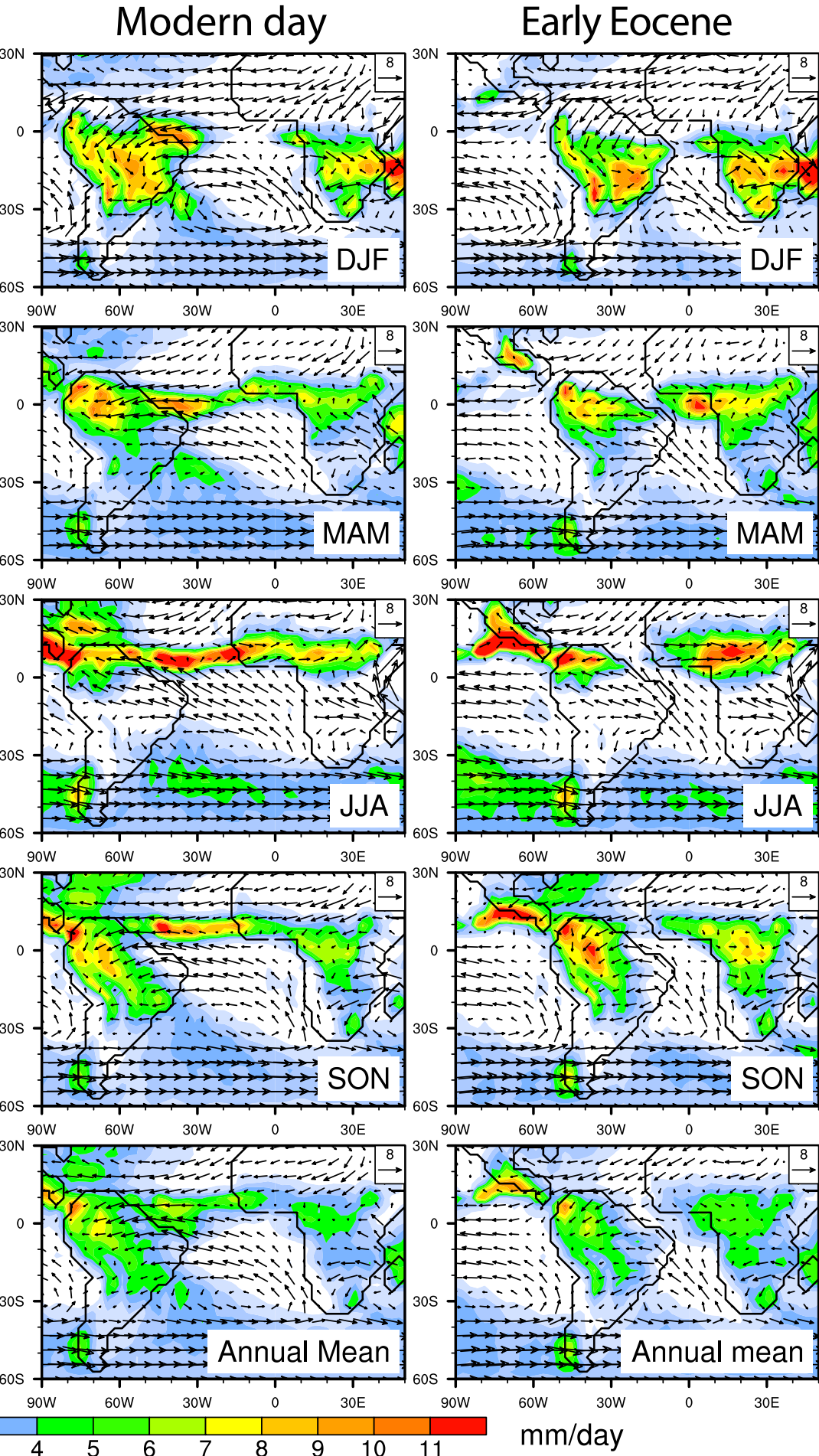

FIG. 1. The seasonal and annual mean climatological precipitation (shading; $\mathrm{mm} \mathrm{day}^{-1}$ ) and $850-\mathrm{hPa}$ winds (vectors; $\mathrm{m} \mathrm{s}^{-1}$ ) for (left) observation and from the (middle) modern-day (Wide_353CO2) experiment and (right) early Eocene (Narrow_1000CO2) experiment. Observed precipitation data are from monthly Climate Prediction Center (CPC) Merged Analysis of Precipitation (CMAP; Xie and Arkin 1997) from January 1979 to December 2010, available online at http://www.esrl.noaa.gov/psd/data/gridded/data.cmap.html. Observed $850-\mathrm{hPa}$ winds are from NCEP2 covering the same period. 
summer when it produces the rainy season of southeastern Brazil.

The major features in the seasonal cycle of the precipitation over tropical South America are fairly well simulated by ECHAM 4.6 (middle panels of Fig. 1). This encourages us to use this model as a framework for examining the effects of variable atmospheric $\mathrm{CO}_{2}$ and variable geometry of the Atlantic basin.

\section{b. Climate of the early Eocene}

In the early Eocene experiment the Atlantic ITCZ is almost completely absent, except at the inner corner of Gulf of Guinea in austral summer and autumn (right panels of Fig. 1). The SAMS still migrates seasonally following the sun as in the modern period, but in general it is weaker and brings precipitation over a smaller region. The SACZ is absent throughout the year. The lowlevel circulation is largely similar in pattern to modern day, except that the trade winds are predominantly in the southwesterly or northwesterly direction with little to no convergence along the equator, consistent with the disappearance of the ITCZ.

The above-mentioned difference in precipitation is better shown by the difference map between early Eocene experiment and modern-day experiment; we use early Eocene minus modern-day experiments (Fig. 2). Note that all the differences we discuss in the paper are statistically significant at a level of $p=0.05$. The model results show that annual mean precipitation was lower in the early Eocene than today throughout all of tropical South America. The area- and annually averaged precipitation over the South American continent decreases by about $15 \%$, from $4.1 \mathrm{~mm} \mathrm{day}^{-1}$ in the modern-day experiment to $3.5 \mathrm{~mm} \mathrm{day}^{-1}$ in the early Eocene experiment (Table 2). This drying occurs in every season and is strongest in austral summer [December-February (DJF)], the rainy season for most of tropical South America (Table 2). In northern tropical South America (box A), there is higher-than-modern precipitation in austral spring [September-November (SON)] and austral winter [June-August (JJA)] and lower-thanmodern precipitation in the other seasons; in far eastern Brazil (box C), precipitation is enhanced during DJF but reduced during the other seasons. The latter finding may be indication of an east-west tropical South America precipitation dipole similar to that previously observed in both model (Liu and Battisti 2015) and proxy observations (Cruz et al. 2009) studies.

Figure 3 shows the seasonal cycles of precipitation area-averaged over the three boxed regions indicated in Fig. 2. These three regions are representative of precipitation in northern South America, central Amazonia, and eastern Brazil, respectively. In northern South
America (box A) today, the rainy season spans boreal spring and boreal autumn with peak rainfall in June (black line). This seasonal cycle is in phase with that of Northern Hemisphere summer monsoon; it is well captured by the modern-day simulation of ECHAM 4.6 except that the precipitation from June to August is weaker than observed. Compared to the modern climate, during the early Eocene, precipitation is greatly reduced throughout much of the year (from December to July) and enhanced from August to November.

In the central Amazon (box B), the observed rainy season lasts from austral spring to early autumn, out of phase with precipitation of northern South America. This feature is roughly captured by the modern-day simulation of ECHAM 4.6. Compared to modern-day simulation, precipitation is reduced in the Amazon region in the early Eocene in almost every month except October and November.

Modern-day precipitation in northeastern Brazil (box C) occurs from austral spring to the end of summer (October-April), with a near-complete absence of precipitation from May to August. This seasonality is well reproduced in the modern-day simulation. Relative to the modern period, precipitation in the early Eocene increases in the peak rainy season, and the dry season is greatly extended to seven months (April-October), resulting in regionally enhanced seasonality in the early Eocene.

\section{c. Mechanisms for the early Eocene drying}

In the remainder of the paper, we focus on discerning the mechanisms responsible for precipitation decrease in the early Eocene. We focus our analysis on DJF because the decrease of DJF precipitation accounts for a major part of the overall drying pattern observed in the early Eocene simulations (Table 2 and Fig. 2). DJF is also the rainy season for most of tropical South America except north of the equator. The unique pattern of early Eocene wetting in SON in northern tropical South America is briefly analyzed and summarized in section $3 \mathrm{~d}$.

Figure 4 shows the difference in DJF precipitation between the early Eocene and modern day (i.e., the combined effect of higher atmospheric $\mathrm{CO}_{2}$ and a narrower Atlantic Ocean), as well as the individual effect of each. Note that precipitation difference in Figs. $4 \mathrm{~b}$ and 4d (also Figs. 4c and 4e) adds up exactly to the precipitation difference shown in Fig. 4a. Narrowing the Atlantic greatly decreases DJF precipitation, independent of the atmospheric $\mathrm{CO}_{2}$ concentration (cf. Figs. $4 \mathrm{~b}$ and $4 \mathrm{c}$ ). Increasing atmospheric $\mathrm{CO}_{2}$ concentration, on the contrary, increases the precipitation, opposing the drying caused by a narrower Atlantic. The decrease in 

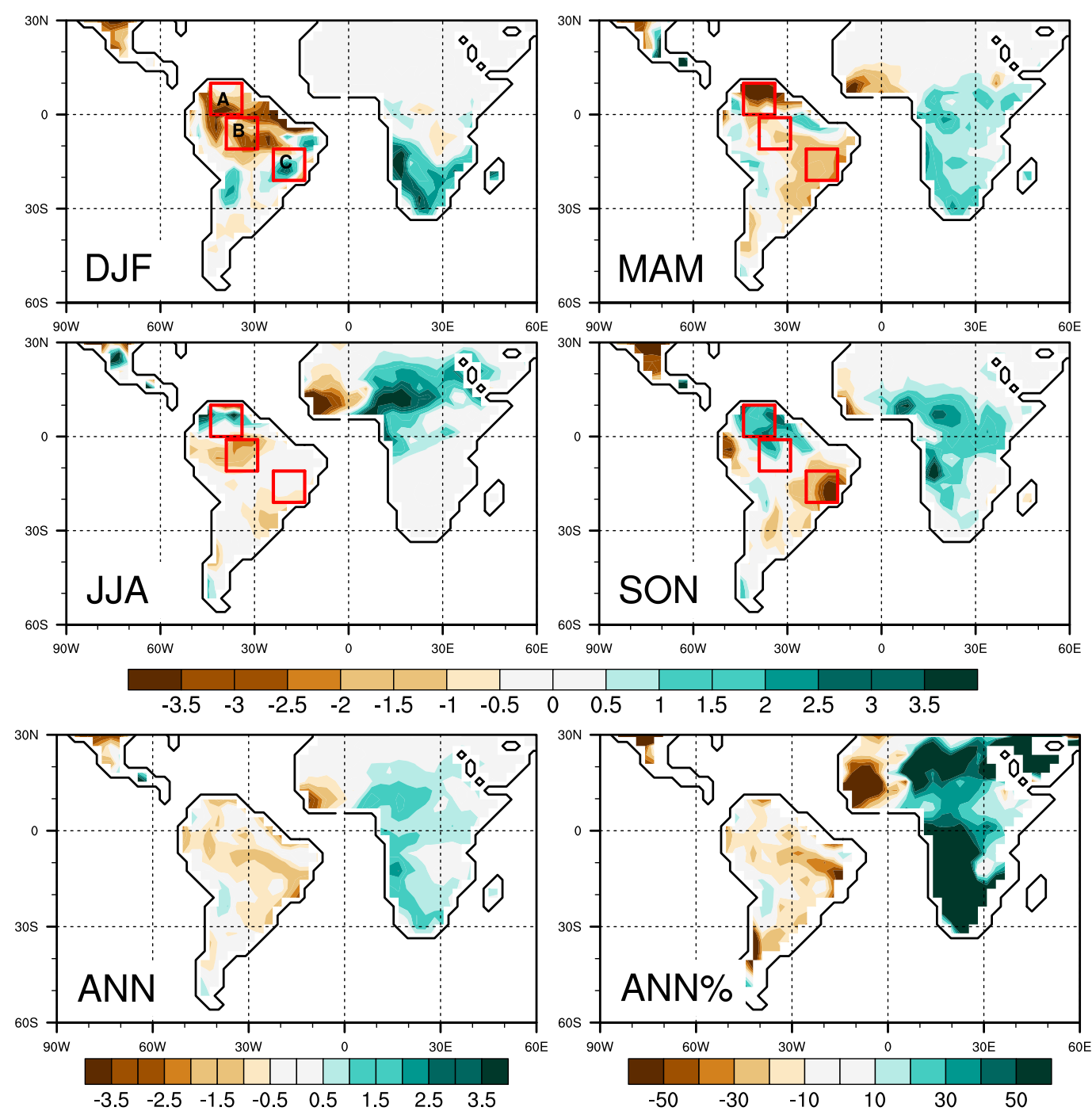

FIG. 2. The difference in seasonal and annual mean precipitation $\left(\mathrm{mm} \mathrm{day}^{-1}\right)$ between the early Eocene (Narrow_1000CO2) and modern-day experiments (Wide_353CO2), that is, differences due to enhanced $\mathrm{CO}_{2}$ and a narrower Atlantic. Precipitation differences over land are calculated as the grid-to-grid difference between Narrow_1000CO2 and Wide_353CO2. Differences over ocean are not shown. (bottom right) The percentage change of annual mean precipitation is calculated as (Narrow_1000CO2/Wide_353CO2) -1$) \times 100$. Red boxes represent the regions over which domain averages are examined in Fig. 3.

DJF precipitation in the early Eocene relative to modern day (Fig. 4a) is due to the impact of a narrower Atlantic basin (Figs. 4b,c).

\section{1) IMPACT OF A NARROWER ATLANTIC OCEAN}

We study the effect of narrowing the Atlantic by examining the water budget over South America. The equation for the conservation of water can be written as

$\frac{\partial W}{\partial t}=E-P-\nabla \cdot \int_{0}^{P_{s}}(q \mathbf{V}) d p=E-P-\int_{0}^{P_{s}} d p \oint q \mathbf{V} d \mathbf{n}$, where $W$ is the column-integrated precipitable water vapor, $P$ is precipitation, $E$ is evaporation, $q$ is specific humidity, $\mathbf{V}$ is wind velocity, $p$ is pressure, $t$ is time, and $\mathbf{n}$ is the outward-pointing unit normal field of $q$. In all of the experiments, the tendency of $W, \partial W / \partial t$, is much smaller than the other terms, indicating that $W$ is in steady state, thus the column-integrated vapor flux convergence over South America equals the difference between precipitation and evaporation. We use monthly climatology data to calculate vapor flux convergence; as a result, the water budget is not closed, likely due to the neglect of submonthly covarying anomalies 
TABLE 2. Precipitation or change in precipitation area averaged over South American continent in units of mm day ${ }^{-1}$.

\begin{tabular}{|c|c|c|c|c|c|}
\hline & DJF & MAM & JJA & SON & Annual \\
\hline Today & 5.4 & 4.4 & 2.2 & 4.3 & 4.1 \\
\hline Early Eocene & 4.5 & 3.5 & 1.8 & 4.0 & 3.5 \\
\hline Early Eocene minus today & -0.9 & -0.9 & -0.4 & -0.3 & -0.6 \\
\hline Impact of geometry at $1000 \mathrm{ppm}(353 \mathrm{ppm})$ & $-1.8(-1.7)$ & $-1.4(-0.9)$ & $-0.6(0.2)$ & $-0.5(0.03)$ & $-1.1(-0.6)$ \\
\hline Impact of $\mathrm{CO}_{2}$ at modern (narrow) Atlantic & $0.8(0.8)$ & $0.6(0.05)$ & $0.2(-0.6)$ & $0.2(-0.2)$ & $0.5(0.00)$ \\
\hline
\end{tabular}

associated with eddies. Nonetheless, the change in the calculated vapor flux convergence qualitatively agrees with what is implied by change in precipitation minus evaporation (Table 3 ).

Comparing the Wide_1000CO2 and Narrow_1000CO2 experiments (Fig. 5a), at a fixed $\mathrm{CO}_{2}$ of $1000 \mathrm{ppm}$, precipitation (area averaged over the entire South American continent) is about $30 \%$ lower with a narrow Atlantic $\left(4.5 \mathrm{~mm} \mathrm{day}^{-1}\right)$ than with a modern Atlantic $\left(6.2 \mathrm{~mm} \mathrm{day}^{-1}\right)$. This difference is almost exclusively due to a decrease in water vapor convergence over South America: the water vapor convergence (inferred as "precipitation minus evaporation") is $1.6 \mathrm{~mm} \mathrm{day}^{-1}$ lower with a narrow ocean than with a wide ocean;
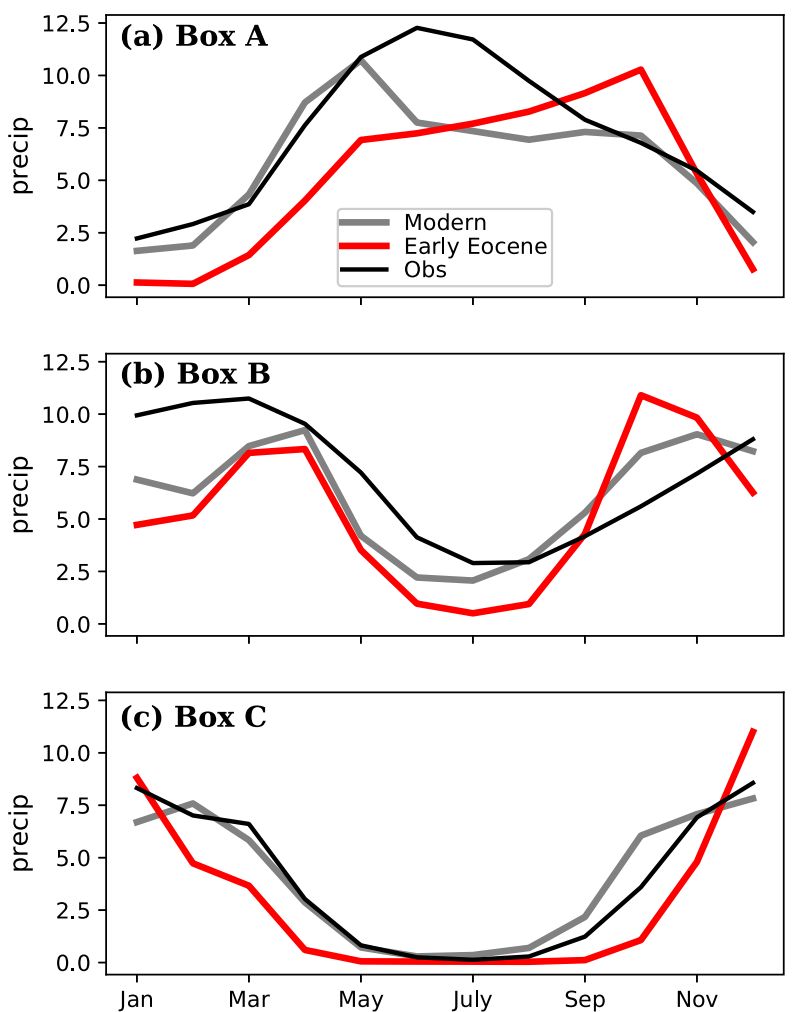

FIG. 3. Seasonal cycle of precipitation $\left(\mathrm{mm} \mathrm{day}^{-1}\right)$ area averaged over the box regions indicated in Fig. 2 from observations (black line), from the modern-day simulation today (Wide_353CO2 experiment; gray line), and from the early Eocene simulation (Narrow_1000CO2 experiment; red line). changes in evaporation flux account for only $0.1 \mathrm{~mm} \mathrm{day}^{-1}$. That the decrease in precipitation is primarily due to decrease in vapor transport is in agreement with results from identical experiments using the CESM 1.2 model, which includes contributions due to transients (Table 3).

The contribution to the total water vapor converged into South America was calculated across each boundary (Fig. 5b). Note that the $x$ axis in Fig. 5b starts in the farthest south and goes northward along the eastern boundary of South America. It continues northwestward to the northern tip of tropical South America, Cape Gallinas at $12^{\circ} \mathrm{N}$, and then returns southward along the western boundary to Cape Horn. The lower water vapor flux into South America in the narrow Atlantic simulation is mostly due to reduction in water vapor advection across the tropical eastern ${ }^{1}$ (from point $\mathrm{B}$ to point $\mathrm{C}$ ) and, especially, the northeastern (from point $\mathrm{C}$ to point $\mathrm{D}$ ) coasts of tropical South America, accounting for $85 \%$ of the total decrease in water vapor delivered to South America in the early Eocene compared to modern climate (Fig. 5c). The smaller changes in water flux across the western (from point $D$ to point $A$ ) and subtropical eastern (from point $\mathrm{A}$ to point $\mathrm{B}$ ) boundaries are model dependent; the same pair of experiments using CESM 1.2 feature the opposite changes as those in ECHAM 4.6 (Table 3).

\section{(i) The northeastern boundary}

Decrease in water flux across the northeastern boundary is predominantly due to a decrease in water vapor in the air crossing the boundary, not due to a decrease in mass flux associated with atmospheric circulation change: when assuming no change in $q$ (light red bars in Fig. 5c), ${ }^{2}$ change in $\mathbf{V}$ alone accounts

\footnotetext{
${ }^{1}$ Note that the definition of "tropical" eastern is arbitrary here. It is defined as the part of eastern boundary where water fluxes into South America; the rest of the eastern boundary is defined as the "subtropical eastern" boundary.

${ }^{2}$ The value of $q$ around the South American continent from Wide_1000CO2 experiment is used for both Wide_1000CO2 and Narrow_1000CO2.
} 


\section{DJF}
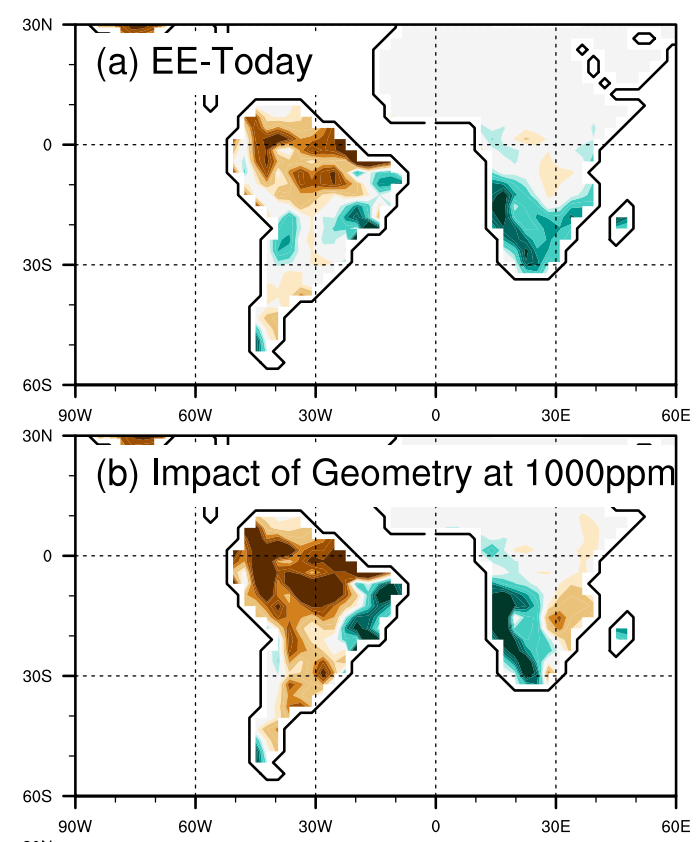

(1)
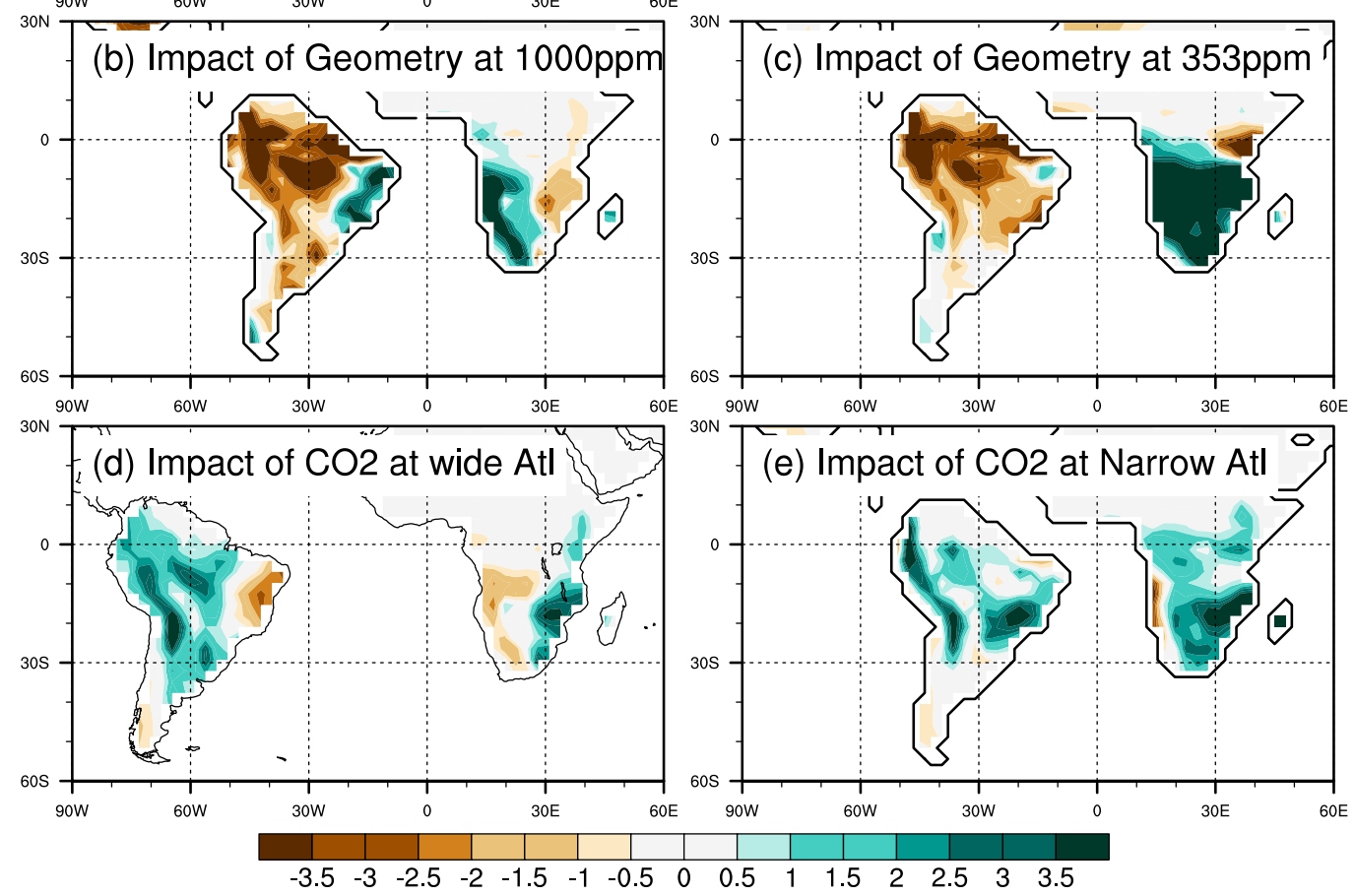

FIG. 4. Changes in precipitation ( $\mathrm{mm} \mathrm{day}^{-1}$ ) during DJF. (a) Early Eocene minus modern day (repeated from Fig. 2). (b) The impact of geometry at 1000-ppm $\mathrm{CO}_{2}$ concentration (i.e., Narrow_1000CO2 minus Wide_1000CO2). (c) The impact of geometry at $353 \mathrm{ppm} \mathrm{CO}$ concentration (i.e., Narrow_353CO2 minus Wide_353CO2). (d) The impact of $\mathrm{CO}_{2}$ concentration with modern Atlantic geometry (i.e., Wide_1000CO2 minus Wide_353CO2). (e) The impact of $\mathrm{CO}_{2}$ concentration with narrow Atlantic geometry (i.e., Narrow_1000CO2 minus Narrow_353CO2).

for only $12 \%$ of the total decrease in water flux across the northeastern boundary.

Water vapor that crosses the boundaries of South America and eventually condenses inland is sourced from evaporation of surface seawater into air parcels. Precipitable water (i.e., the total water vapor amount contained in the air column) increases from northern Africa toward the northeastern coast of South America and from the southeastern Atlantic toward the eastern coast of South America (Figs. 6a,b), in the same direction as the trade winds in each hemisphere (Figs. 6e,f). This suggests that the water vapor that enters South America is accumulated through surface evaporation as air parcels transit across the tropical Atlantic Ocean.

To determine why there is less water vapor in the air parcels across the northeastern boundary when the Atlantic is narrower, we calculate the amount of water vapor accumulated by an air parcel, following its trajectory from eastern Atlantic to South America (Fig. 6). That is, we calculate the total water vapor that can be evaporated into the boundary layer on its passage from the eastern Atlantic to South America:

$$
q\left(\mathbf{x}_{f}\right)=q\left(\mathbf{x}_{0}\right)+\int_{t_{0}}^{t_{f}} E(\mathbf{s}, t) d \mathbf{s}
$$


TABLE 3. Changes in DJF precipitation, evaporation, precipitation minus evaporation, and water vapor flux between Narrow $1000 \mathrm{CO} 2$ and Wide_1000CO2. All quantities are area averaged over South America and have units of mm day ${ }^{-1}$.

\begin{tabular}{lcc}
\hline \hline & ECHAM 4.6 & CESM 1.2 \\
\hline Precipitation & -1.76 & -1.09 \\
Evaporation & -0.10 & -0.19 \\
Precipitation minus evaporation & -1.66 & -0.90 \\
$\quad$ Water vapor convergence & -3.04 & -1.77 \\
$\quad$ Water flux across subtropical eastern & 0.31 & -0.38 \\
$\quad$ boundary & -1.24 & -1.02 \\
$\quad$ Water flux across tropical eastern & & \\
$\quad$ boundary & -1.65 & -0.99 \\
$\quad$ Water flux across northeastern & & \\
$\quad$ boundary & -0.46 & 0.61 \\
\hline
\end{tabular}

where $E(\mathbf{s}, t)$ is evaporation, $q\left(\mathbf{x}_{0}\right)$ is the amount of water vapor in the air parcel when it leaves Africa and South Atlantic Ocean, and $\mathbf{s}$ is the location of the air parcel at time $t$, which is a function of its initial location $x_{0}$ and the wind velocity $\mathbf{v}$ :

$$
\mathbf{s}=\mathbf{x}_{0}+\int_{t_{0}}^{t} \mathbf{v} d t
$$

The solution to this equation represents the upper limit of the total water vapor in the air column, assuming zero initial moisture content, that is, $q\left(\mathbf{x}_{0}\right)=0$. We take $\mathbf{v}$ to be the wind velocity at $925 \mathrm{hPa}$, which is representative of flow in the boundary layer.

For both experiments, the amount of water vapor in the air parcels increases along the trajectories (Figs. 6a,b). This is consistent with the accumulation of evaporated seawater during the transit of air parcels across the ocean (Figs. 6c,d). In the wide Atlantic experiment, it takes air parcels, on average, over 6 days (Fig. 6c) to transit the Atlantic. In the narrow Atlantic experiment, this transit time is reduced to just over 2 days (Fig. 6d). Despite a higher evaporation rate in the narrow Atlantic experiment (Figs. 6e,f), air parcels contain much less water vapor when arriving at South America. This implies that it

(a) Water budget terms area-averaged over South America
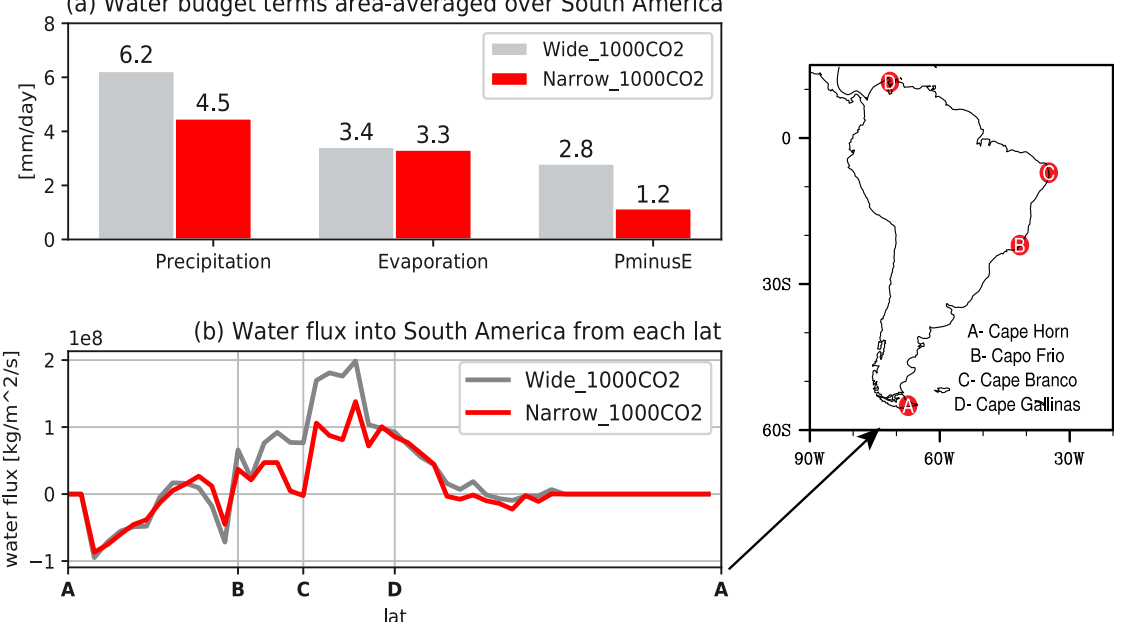

(c) Water flux into South America from each boundary

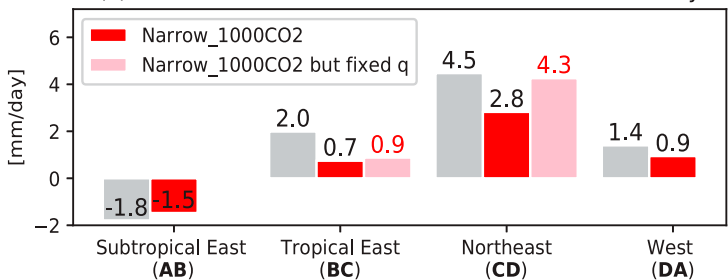

FIG. 5. Water budget for DJF in the Wide_1000CO2 (gray) and the Narrow_1000CO2 (red) experiments. (a) Precipitation, evaporation, and precipitation minus evaporation, all area averaged over the entire South American continent. All quantities are converted to mm day ${ }^{-1}$. Convergence of water flux is calculated as the sum of water flux into South America across all boundaries shown in (b). (right) Locations of the boundary points are shown in the map. (b) Vertically integrated water vapor flux into South America across each boundary $\left(\mathrm{kg} \mathrm{m}^{-2} \mathrm{~s}^{-1}\right)$ as a function of latitude. (c) Total water flux into South America across each boundary. In (c) water vapor flux is converted to $\mathrm{mm} \mathrm{day}^{-1}$ by dividing the value by the area of South America. 

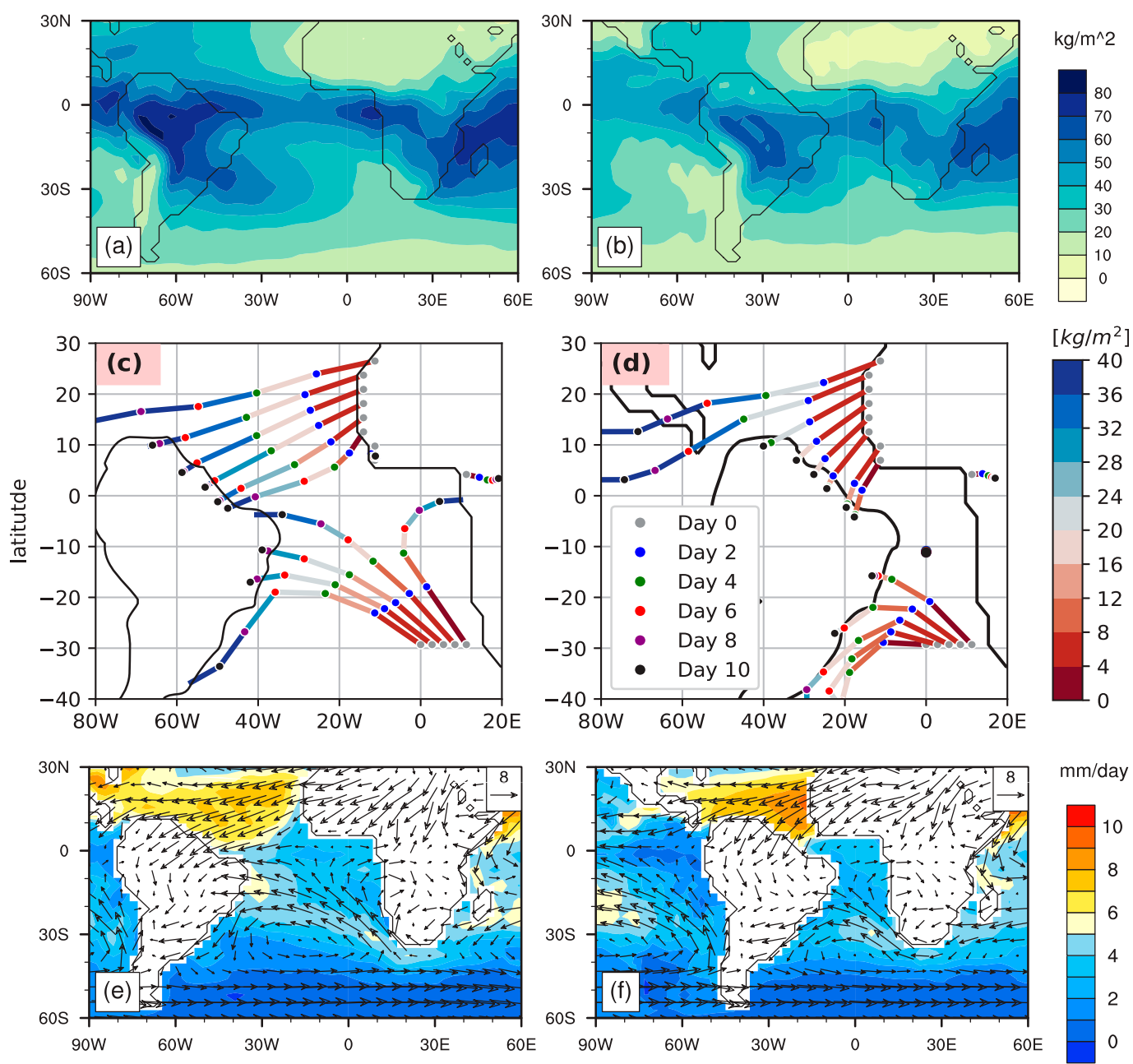

FIG. 6. (a),(b) Total precipitable water $\left(\mathrm{kg} \mathrm{m}^{-2}\right)$, (c),(d) the integrated evaporative flux from seawater into the atmosphere $\left(\mathrm{kg} \mathrm{m}^{-2}\right)$ along the trajectory of climatological $925-\mathrm{hPa}$ winds, and (e),(f) evaporation (shading) and winds at 925-hPa (vectors; $\mathrm{m} \mathrm{s}^{-1}$ ) from (left) theWide_1000CO2 experiment and (right) the Narrow_1000CO2 experiment. Trajectories in (c) and (d) are terminated after reaching South America.

is the shorter residence time over the ocean that accounts for the reduction in water vapor content and hence water flux into South America across the northeastern boundary.

\section{(ii) The tropical eastern boundary}

The decrease in water flux across the tropical eastern boundary, however, is mainly due to a decrease in mass flux across the boundaries (cf. dark and light red bars in Fig. 5c): change in $\mathbf{V}$ alone (light red bars in Fig. 5c) accounts for $85 \%$ of the total decrease in water flux across the tropical eastern boundary. The changes in mass flux are related to changes in the southeasterly trades. Compared with the wide Atlantic geometry, the southeasterly trades in a narrow Atlantic are weaker and located more southward (cf. Figs. 6e and 6f). As a result, a part of water vapor is transported back to over the ocean following the South Atlantic subtropical anticyclone, rather than across the eastern boundary into South America as in the case of a wide Atlantic (cf. trajectories in Figs. $6 c$ and $6 d$ ).

\section{2) IMPACT OF HIGHER ATMOSPHERIC $\mathrm{CO}_{2}$ CONCENTRATION}

In a fixed modern geometry, increasing atmospheric $\mathrm{CO}_{2}$ concentration from 353 to $1000 \mathrm{ppm}$ increases the precipitation in the interior of the South American continent (Fig. 4d), enhancing the mean precipitation during DJF (cf. middle panels of Fig. 1). This enhancement due to increased $\mathrm{CO}_{2}$ is largely independent of Atlantic geometry (cf. Figs. 4d and 4e; Table 2). We note that the precipitation increase over the subtropical 

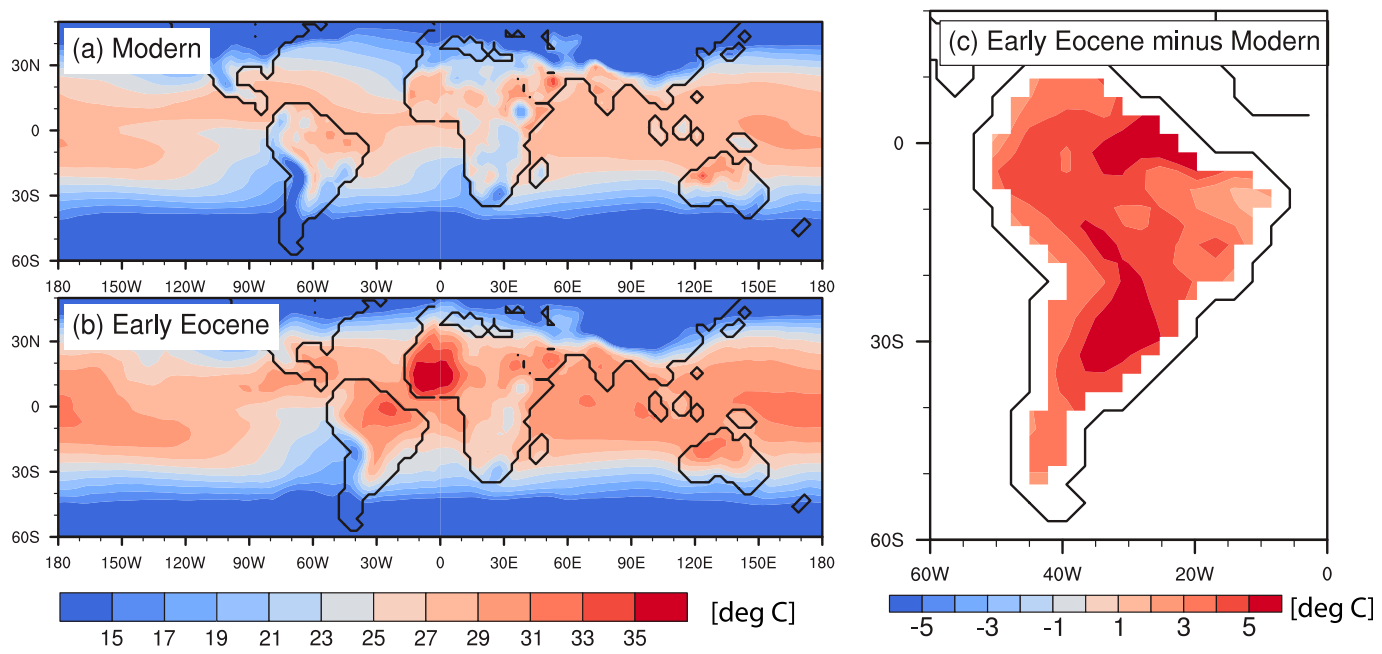

FIG. 7. The annual mean surface temperature $\left({ }^{\circ} \mathrm{C}\right)$ for the (a) modern-day experiment and (b) early Eocene experiment. (c) The difference of (b) minus (a).

South Atlantic due to increased $\mathrm{CO}_{2}$ is in accord with the influence of future atmospheric increases simulated by the IPCC Fifth Assessment Report models—in fact, subtropical South America is the only place on Earth where over $90 \%$ of climate models agree on the sign of the future change in precipitation (IPCC 2013).

We diagnose the impact of increasing atmospheric $\mathrm{CO}_{2}$ in the same way as for narrowing the Atlantic (figures not shown). The precipitation enhancement over the Amazon is from both enhancement of local evaporation and increase of moisture transport into Amazon, both of which are related to the warming caused by higher atmospheric $\mathrm{CO}_{2}$ (Fig. 7): higher atmospheric $\mathrm{CO}_{2}$ warms the South American continent and hence local evaporation; higher atmospheric $\mathrm{CO}_{2}$ also warms the surface of tropical Atlantic Ocean, which increases the evaporation of seawater and hence moisture transport into South America. The increase in local evaporation and moisture transport into South America increases moisture content in the boundary layer, reduces the gross moist stability, and enhances convection (Fu et al. 1999; Chou and Neelin 2004).

\section{d. Precipitation change during SON}

Unlike the case for DJF, SON precipitation is enhanced in the early Eocene experiment in northern South America (and reduced in the eastern coast) (Fig. 8a). This precipitation change is caused by both narrowing the Atlantic and increasing atmospheric $\mathrm{CO}_{2}$ (cf. Figs. 8b-e with Fig. 8a), with a possible contribution from potential changes in ocean circulation (see section 4b). Nonlinearity also seems to play a role: the impact of narrowing the Atlantic depends on $\mathrm{CO}_{2}$ concentration and the impact of increasing $\mathrm{CO}_{2}$ depends on the
Atlantic width. Reasons for the precipitation change in SON are complex and beyond the scope of this paper.

\section{Discussion}

\section{a. Comparison with proxy record}

Paleotemperature estimates using oxygen isotope composition and $\mathrm{Mg} / \mathrm{Ca}$ from planktonic foraminiferal calcite shells and tetraether index of 86 carbon atoms $\left(\mathrm{TEX}_{86}\right)$ from the tropical deep ocean drilling sites show that the tropical ocean was warmer in the Eocene than it is today (Zachos et al. 1994; Pearson et al. 2001; Tripati et al. 2003; Lunt et al. 2012). However, the uncertainty range is large regarding how much warmer the tropical ocean was. Depending on the assumptions made and the calibration method used, the Eocene tropical sea surface temperature estimates range between $28^{\circ}$ and $40^{\circ} \mathrm{C}$ (Huber 2008), making it $0^{\circ}-12^{\circ} \mathrm{C}$ warmer than modern day. In our simulations, tropical sea surface temperature in the early Eocene are up to $4^{\circ} \mathrm{C}$ higher than in the modern day (Fig. 7). This is within the range of paleotemperature estimates (e.g., Cramwinckel et al. 2018).

Over continental South America, the Eocene was warmer than modern day in our model in every season. This is expected because of the higher-than-modern concentrations of atmospheric $\mathrm{CO}_{2}$. However, there are no proxy paleotemperature records from South America to verify whether the magnitude of warming in our model is reasonable.

Eocene precipitation proxies from South America are very scarce. Pollen and spore records from central Colombia and western Venezuela show a peak of flora diversity occurring in the early Eocene (Jaramillo et al. 


\section{SON}
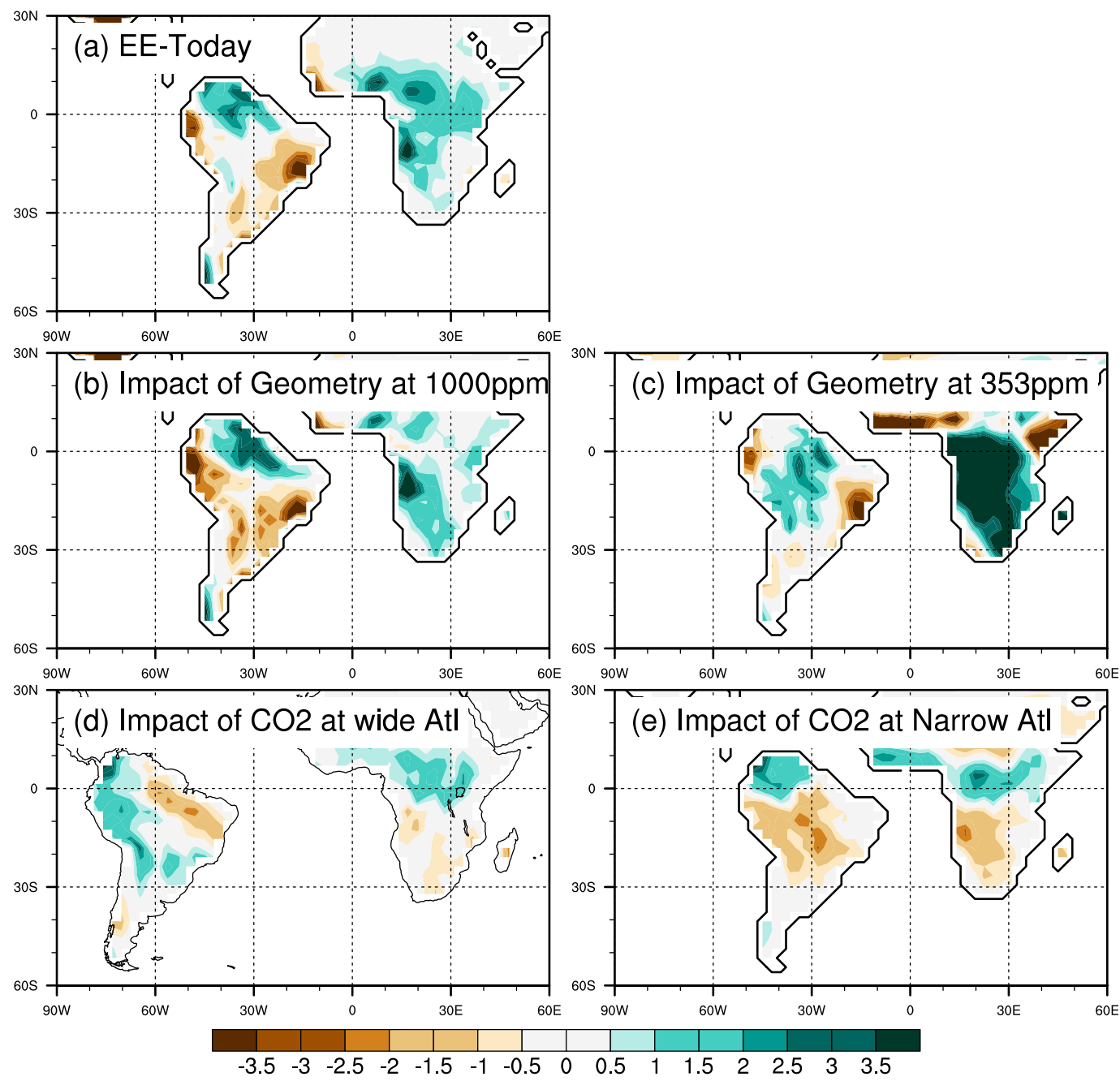

FIG. 8. As in Fig. 4, but for SON.

2006). This, however, does not necessarily suggest a wetter climate in the early Eocene given that biodiversity is related to climate in a more complicated way.

Note that although proxy records exist for the midlatitude Eocene climate, we must refrain from comparing these data to our model results in these regions because there are additional differences between the Eocene and modern climate that are likely to impact the mid- and high-latitude climate; these include the lack of a Drake Passage, the nonexistence of the Isthmus of Panama, and the more southerly latitude of the southern tip of Africa, all of which have been shown to affect the ocean overturning circulation and thus may have impacted the high-latitude climate in both hemispheres [see, e.g., Ferreira et al. (2018) and references therein]. Changes in high latitudes will have little impact on our conclusions, which are based on the tropical and subtropical responses, as recent work suggests that high-latitude temperature changes have little impact on tropical and subtropical circulation (Bonan et al. 2018; Shaw and Tan 2018; Chemke and Polvani 2019). The poles can only affect the tropics when the sea ice extends far south from where it is today (e.g., in the last glacial period). In the Eocene and in our simulations, however, the sea ice extent is poleward of where it is today.

\section{b. Impact of ocean circulation change}

By using ECHAM 4.6 coupled to a slab ocean, this study does not allow for changes in ocean circulation that might arise in a narrower Atlantic. To explore whether such changes might be important for changes in precipitation, we performed a sensitivity experiment in which we reran the Narrow_1000CO2 experiment but set the slab-ocean $Q$ flux in the tropical $\left(20^{\circ} \mathrm{S}-20^{\circ} \mathrm{N}\right)$ 

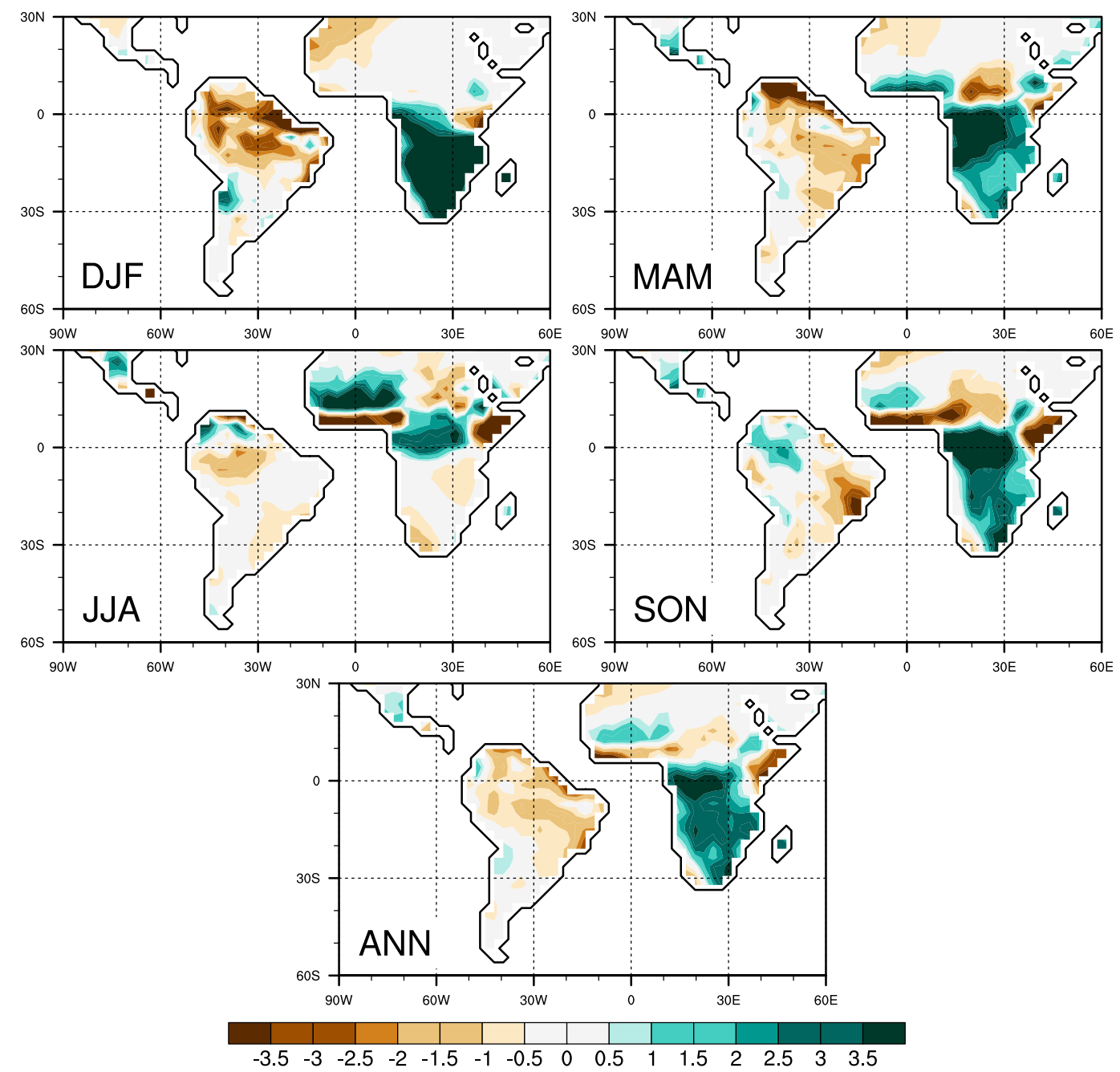

FIG. 9. As in Fig. 2, except that a draconian change in "ocean circulation" (see the text) is included in the early Eocene experiment.

Atlantic to zero. Although setting the $Q$ flux to zero is arbitrary, it is such a significant perturbation that it likely provides a reasonable test of the influence of Atlantic Ocean circulation on the magnitude of precipitation change. With "ocean circulation change" considered, the difference in precipitation in tropical South America between the early Eocene and modern day is almost identical to that when ocean circulation change is neglected (cf. Figs. 9 and 2). This suggests that changes in ocean circulation have a negligible effect on precipitation in tropical South America compared to that of increasing $\mathrm{CO}_{2}$ and narrowing the Atlantic basin.

\section{c. Dependence on $\mathrm{CO}_{2}$ concentration}

In this study we use $1000 \mathrm{ppm}$ for atmospheric $\mathrm{CO}_{2}$ concentration in the early Eocene, although estimates for this time vary between 500 and $1500 \mathrm{ppm}$. Due to the compensation we find between the narrow Atlantic and increased $\mathrm{CO}_{2}$, the amplitude of drying over South America may depend on the value of $\mathrm{CO}_{2}$ concentration; however, Table 2 shows that, during DJF, the precipitation increase from $\mathrm{CO}_{2}$ would need to be twice as large as in our simulations to completely cancel the precipitation reduction from the $\mathrm{CO}_{2}$ narrowed Atlantic.

The competing effects of drying from Atlantic narrowing, and wetting from an increase, may help explain why models disagree on the sign of the change in this region [e.g., CCSM3 in Huber and Caballero (2011) vs ECHAM5 in Heinemann et al. (2009); also cf. Figs. 1 and 7 of Carmichael et al. (2016)]: models in which precipitation is more sensitive to $\mathrm{CO}_{2}$ or use a much higher atmospheric $\mathrm{CO}_{2}$ concentration are more likely to show wetting overall. 
To explore whether the primary results are model dependent, we repeated all the experiments with CESM 1.2 and found qualitatively similar results: a drier early Eocene compared to the modern climate, with the drying effects of narrowing the Atlantic overwhelming the wetting effects of increasing the atmospheric $\mathrm{CO}_{2}$. Both ECHAM 4.6 and CESM 1.2 show that narrowing the Atlantic dries tropical South America, and that the drying is primarily due to a decrease in water vapor flux into South America across the northeast boundary (Table 3), which is due to a decrease in the distance over which the air travels across the ocean before reaching the coastline.

\section{Conclusions}

Proxy records show that global climate during the early Eocene was very different from modern climate, but we know very little about South American climate from the same period. In this study, we examined the impact of changes in the two boundary conditions that are likely to have been most important for tropical South American climate during the early Eocene: a higher atmospheric concentration and a narrower Atlantic basin. Both the ECHAM 4.6 and CESM 1.2 models, coupled to a slab ocean, produce the same qualitative results. Narrowing the Atlantic on its own decreases the precipitation of South America and increasing atmospheric $\mathrm{CO}_{2}$ on its own increases South American precipitation. Combining both factors, the effect of geometry is greater than the effect of $\mathrm{CO}_{2}$, producing a significantly drier climate in tropical South America for early Eocene conditions than for modern in both models. We anticipate being able to test this result in the upcoming Trans-Amazon Drilling Project that intends to recover Eocene sediments from depositional basins across the Amazon region (Baker et al. 2015).

Analysis of the water budget shows that the drying of tropical South America under a narrower Atlantic geometry is due to both a reduction in the water vapor transported into South America and changes in the atmospheric circulation. For both narrow and wide Atlantic basins, the water vapor that flows into and condenses over South America is accumulated in the lower atmosphere as air parcels transit across the tropical Atlantic Ocean. When the Atlantic is narrower, air parcels traveling across the ocean have less time to pick up water from the ocean below; as a result, they contain much less vapor when crossing the coastline of South America. The southeasterly trades are also weaker and located more southward when the Atlantic is narrower (cf. Figs. 6e and 6f), transporting less water vapor across the eastern boundary into South America.
Despite the dependence on $\mathrm{CO}_{2}$ concentrations, our results support the likelihood of a new view of the early Eocene climate of the Amazon with very warm and relatively dry conditions. Together, these would suggest lower effective moisture, lower soil moisture, and lower runoff, all conditions that would seem inimical to forest biota. If validated by forthcoming drilling expeditions, this result begs the question: were early Eocene forests present in the Amazon or was the region occupied by savanna? If the latter, then phylogenetic analyses of Amazon biota will have to be interpreted in a very different context from present understanding.

Acknowledgments. We thank Dr. Matt Huber for helpful comments on the impact of $Q$-flux boundary conditions on Eocene simulations using an earlier version of CAM. We also thank three anonymous reviewers whose comments greatly helped improve our paper. The authors were supported by grants from the National Science Foundation (Division of Earth Sciences, Frontiers in Earth-System Dynamics Award 1338694). R. White was also funded by the JISAO postdoc fellowship and the Tamaki Foundation.

\section{REFERENCES}

Anagnostou, E., and Coauthors, 2016: Changing atmospheric $\mathrm{CO}_{2}$ concentration was the primary driver of early Cenozoic climate. Nature, 533, 380-384, https://doi.org/10.1038/nature17423.

Antonelli, A., A. Zizka, F. A. Carvalho, R. Scharn, C. D. Bacon, D. Silvestro, and F. L. Condamine, 2018: Amazonia is the primary source of Neotropical biodiversity. Proc. Natl. Acad. Sci. USA, 115, 6034-6039, https://doi.org/10.1073/pnas.1713819115.

Baker, P., and Coauthors, 2015: Trans-Amazon Drilling Project (TADP): Origins and evolution of the forests, climate, and hydrology of the South American tropics. Sci. Drill., 20, 41-49, https://doi.org/10.5194/SD-20-41-2015.

Beerling, D. J., and D. L. Royer, 2011: Convergent Cenozoic $\mathrm{CO}_{2}$ history. Nat. Geosci., 4, 418-420, https://doi.org/10.1038/ ngeo1186.

Bonan, D., K. Armour, G. Roe, N. Siler, and N. Feldl, 2018: Sources of uncertainty in the meridional pattern of climate change. Geophys. Res. Lett., 45, 9131-9140, https://doi.org/ 10.1029/2018GL079429.

Caballero, R., and M. Huber, 2013: State-dependent climate sensitivity in past warm climates and its implications for future climate projections. Proc. Natl. Acad. Sci. USA, 110, 14162 14167, https://doi.org/10.1073/pnas.1303365110.

Carmichael, M. J., and Coauthors, 2016: A model-model and datamodel comparison for the early Eocene hydrological cycle. Climate Past, 12, 455-481, https://doi.org/10.5194/cp-12-455-2016.

Chemke, R., and L. M. Polvani, 2019: Exploiting the abrupt $4 \times \mathrm{CO}_{2}$ scenario to elucidate tropical expansion mechanisms. J. Climate, 32, 859-875, https://doi.org/10.1175/JCLI-D-18-0330.1.

Chou, C., and J. D. Neelin, 2004: Mechanisms of global warming impacts on regional tropical precipitation. J. Climate, 17, 2688-2701, https://doi.org/10.1175/1520-0442(2004)017<2688: MOGWIO $>2.0 . \mathrm{CO} ; 2$. 
Close, R. A., and Coauthors, 2019: Diversity dynamics of Phanerozoic terrestrial tetrapods at the local-community scale. Nat. Ecol. Evol., 3, 590-597, https://doi.org/10.1038/s41559-0190811-8.

Condamine, F. L., K. L. Silva-Brandão, G. J. Kergoat, and F. A. Sperling, 2012: Biogeographic and diversification patterns of Neotropical Troidini butterflies (Papilionidae) support a museum model of diversity dynamics for Amazonia. BMC Evol. Biol., 12, 82, https://doi.org/10.1186/1471-2148-12-82.

Cramwinckel, M. J., and Coauthors, 2018: Synchronous tropical and polar temperature evolution in the Eocene. Nature, 559 382, https://doi.org/10.1038/s41586-018-0272-2.

Cruz, F. W., and Coauthors, 2009: Orbitally driven east-west antiphasing of South American precipitation. Nat. Geosci., 2, 210-214, https://doi.org/10.1038/ngeo444.

Ehlers, T. A., and C. J. Poulsen, 2009: Influence of Andean uplift on climate and paleoaltimetry estimates. Earth Planet. Sci. Lett., 281, 238-248, https://doi.org/10.1016/j.epsl.2009.02.026.

Ferreira, D., and Coauthors, 2018: Atlantic-Pacific asymmetry in deep water formation. Annu. Rev. Earth Planet. Sci., 46, 327-352, https://doi.org/10.1146/ANNUREV-EARTH-082517-010045.

Fu, R., B. Zhu, and R. E. Dickinson, 1999: How do atmosphere and land surface influence seasonal changes of convection in the tropical Amazon? J. Climate, 12, 1306-1321, https://doi.org/ 10.1175/1520-0442(1999)012<1306:HDAALS>2.0.CO;2.

Garreaud, R., and J. M. Wallace, 1998: Summertime incursions of midlatitude air into subtropical and tropical South America. Mon. Wea. Rev., 126, 2713-2733, https://doi.org/10.1175/15200493(1998)126<2713:SIOMAI >2.0.CO;2.

—, M. Vuille, R. Compagnucci, and J. Marengo, 2009: Present-day South American climate. Palaeogeogr. Palaeoclimatol. Palaeoecol., 281, 180-195, https://doi.org/10.1016/j.palaeo.2007.10.032.

_- A. Molina, and M. Farias, 2010: Andean uplift, ocean cooling and Atacama hyperaridity: A climate modeling perspective. Earth Planet. Sci. Lett., 292, 39-50, https://doi.org/10.1016/ j.epsl.2010.01.017.

Garzione, C. N., and Coauthors, 2017: Tectonic evolution of the Central Andean plateau and implications for the growth of plateaus. Annu. Rev. Earth Planet. Sci., 45, 529-559, https:// doi.org/10.1146/annurev-earth-063016-020612.

Heinemann, M., J. Jungclaus, and J. Marotzke, 2009: Warm Paleocene/Eocene climate as simulated in ECHAM5/MPIOM. Climate Past, 5, 785-802, https://doi.org/10.5194/cp-5785-2009.

Huber, M., 2008: A hotter greenhouse? Science, 321, 353-354, https://doi.org/10.1126/science.1161170.

— thermal gradients: Coupled simulation of an Eocene greenhouse climate. Geophys. Res. Lett., 28, 3481-3484, https:// doi.org/10.1029/2001GL012943.

— problem revisited. Climate Past, 7, 603, https://doi.org/10.5194/ cp-7-603-2011.

— , H. Brinkhuis, C. E. Stickley, K. Döös, A. Sluijs, J. Warnaar, S. A. Schellenberg, and G. L. Williams, 2004: Eocene circulation of the Southern Ocean: Was Antarctica kept warm by subtropical waters? Paleoceanography, 19, PA4026, https:// doi.org/10.1029/2004PA001014.

IPCC, 2013: Climate Change 2013: The Physical Science Basis. T. F. Stocker et al., Eds., Cambridge University Press, 1535 pp.

Jaramillo, C., M. J. Rueda, and G. Mora, 2006: Cenozoic plant diversity in the Neotropics. Science, 311, 1893-1896, https:// doi.org/10.1126/science.1121380.
Jones, C., and Coauthors, 2011: The HadGEM2-ES implementation of CMIP5 centennial simulations. Geosci. Model Dev., 4, 543-570, https://doi.org/10.5194/gmd-4-543-2011.

Kodama, Y.-M., 1993: Large-scale common features of subtropical convergence zones (the Baiu frontal zone, the SPCZ and the SACZ). Part II: Conditions of the circulations for generating the STCZs. J. Meteor. Soc. Japan, 71, 581-610, https://doi.org/ 10.2151/jmsj1965.71.5_581.

Lagabrielle, Y., Y. Goddéris, Y. Donnadieu, J. Malavieille, and M. Suarez, 2009: The tectonic history of Drake Passage and its possible impacts on global climate. Earth Planet. Sci. Lett., 279, 197-211, https://doi.org/10.1016/j.epsl.2008.12.037.

Lenters, J. D., and K. Cook, 1995: Simulation and diagnosis of the regional summertime precipitation climatology of South America. J. Climate, 8, 2988-3005, https://doi.org/10.1175/ 1520-0442(1995)008<2988:SADOTR >2.0.CO;2.

Liu, X., and D. S. Battisti, 2015: The influence of orbital forcing of tropical insolation on the climate and isotopic composition of precipitation in South America. J. Climate, 28, 4841-4862, https://doi.org/10.1175/JCLI-D-14-00639.1.

Lunt, D. J., P. J. Valdes, T. D. Jones, A. Ridgwell, A. M. Haywood, D. N. Schmidt, R. Marsh, and M. Maslin, 2010: $\mathrm{CO}_{2}$-driven ocean circulation changes as an amplifier of PaleoceneEocene thermal maximum hydrate destabilization. Geology, 38, 875-878, https://doi.org/10.1130/G31184.1. , and Coauthors, 2012: A model-data comparison for a multimodel ensemble of early Eocene atmosphere-ocean simulations: EoMIP. Climate Past, 8, 1717-1736, https://doi.org/ 10.5194/cp-8-1717-2012.

Nilsson, J., P. L. Langen, D. Ferreira, and J. Marshall, 2013: Ocean basin geometry and the salinification of the Atlantic Ocean. J. Climate, 26, 6163-6184, https://doi.org/10.1175/JCLI-D-1200358.1.

Nogués-Paegle, J., and K. C. Mo, 1997: Alternating wet and dry conditions over South America during summer. Mon. Wea. Rev., 125, 279-291, https://doi.org/10.1175/1520-0493(1997) $125<0279$ :AWADCO $>2.0 . \mathrm{CO} ; 2$

O'Dea, A., and Coauthors, 2016: Formation of the Isthmus of Panama. Sci. Adv., 2, e1600883, https://doi.org/10.1126/ sciadv.1600883.

Pearson, P. N., P. W. Ditchfield, J. Singano, K. G. Harcourt-Brown, C. J. Nicholas, R. K. Olsson, N. J. Shackleton, and M. A. Hall, 2001: Warm tropical sea surface temperatures in the late Cretaceous and Eocene epochs. Nature, 413, 481-487, https:// doi.org/10.1038/35097000.

Roeckner, E., and Coauthors, 1996: The atmospheric general circulation model ECHAM-4: Model description and simulation of present-day climate. Rep. 218, Max Planck Institute for Meteorology, $90 \mathrm{pp}$.

Scher, H. D., and E. E. Martin, 2006: Timing and climatic consequences of the opening of Drake Passage. Science, 312, 428430, https://doi.org/10.1126/science.1120044.

Seton, M., and Coauthors, 2012: Global continental and ocean basin reconstructions since 200 Ma. Earth Sci. Rev., 113, 212270, https://doi.org/10.1016/j.earscirev.2012.03.002.

Shaw, T. A., and Z. Tan, 2018: Testing latitudinally dependent explanations of the circulation response to increased $\mathrm{CO}_{2}$ using aquaplanet models. Geophys. Res. Lett., 45, 9861-9869, https://doi.org/10.1029/2018GL078974.

Takahashi, K., and D. S. Battisti, 2007: Processes controlling the mean tropical Pacific precipitation pattern. Part I: The Andes and the eastern Pacific ITCZ. J. Climate, 20, 3434-3451, https://doi.org/10.1175/JCLI4198.1. 
Tripati, A. K., M. L. Delaney, J. C. Zachos, L. D. Anderson, D. C. Kelly, and H. Elderfield, 2003: Tropical sea-surface temperature reconstruction for the early Paleogene using $\mathrm{Mg} / \mathrm{Ca}$ ratios of planktonic foraminifera. Paleoceanography, 18, 1101, https://doi.org/10.1029/2003PA000937.

Vera, C., and Coauthors, 2006: Toward a unified view of the American monsoon systems. J. Climate, 19, 4977-5000, https:// doi.org/10.1175/JCLI3896.1.

Wara, M. W., A. C. Ravelo, and M. L. Delaney, 2005: Permanent El Niño-like conditions during the Pliocene warm period. Science, 309, 758-761, https://doi.org/10.1126/science.1112596.

Winguth, A., C. Shellito, C. Shields, and C. Winguth, 2010: Climate response at the Paleocene-Eocene thermal maximum to greenhouse gas forcing-A model study with CCSM3. J. Climate, 23, 2562-2584, https://doi.org/10.1175/2009JCLI3113.1.
Xie, P., and P. A. Arkin, 1997: Global precipitation: A 17-year monthly analysis based on gauge observations, satellite estimates, and numerical model outputs. Bull. Amer. Meteor. Soc., 78, 2539-2558, https://doi.org/10.1175/1520-0477(1997)078<2539: GPAYMA $>2.0 . \mathrm{CO} ; 2$.

Zachos, J. C., L. D. Stott, and K. C. Lohmann, 1994: Evolution of early Cenozoic marine temperatures. Paleoceanogr. Paleoclimatol., 9, 353-387, https://doi.org/10.1029/93PA03266.

_-, M. Pagani, L. Sloan, E. Thomas, and K. Billups, 2001: Trends, rhythms, and aberrations in global climate 65 Ma to present. Science, 292, 686-693, https://doi.org/10.1126/ science.1059412.

Zhou, J., and K. Lau, 1998: Does a monsoon climate exist over South America? J. Climate, 11, 1020-1040, https://doi.org/ 10.1175/1520-0442(1998)011<1020:DAMCEO>2.0.CO;2. 